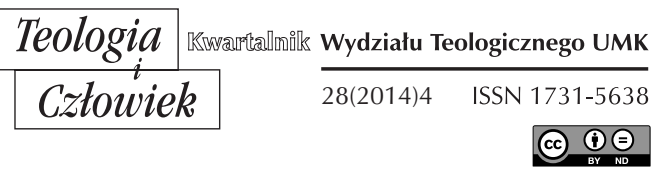

ANDRZEJ T. KUBANOWSKI*

TORUŃ

\title{
CONFORMITAS CHRISTI - KU CHRYSTIANOLOGII JAKO NAUCE O BYCIU CHRZEŚCIJANINEM
}

DOI: http://dx.doi.org/10.12775/TiCz.2014.058

W świetle współczesnej refleksji nad treściami znajdującymi się $\mathrm{w}$ Corpus Paulinum oraz przy ponownym spojrzeniu na nie $\mathrm{w}$ perspektywie całościowej paraklezy (odrzucając ich zbytnią strukturalizację, do czego namawiał już m.in. o. Servais T. Pinckaers OP) $)^{1}$ ukazuje się, jeszcze niewystarczająco opracowana, nowa interpretacja antropologii według św. Pawła $^{2}$. Jest to interpretacja, która wykazuje, że w Pawłowym nauczaniu tylko niewielki akcent pada na rozważania dotyczące ogólnej koncepcji

* Andrzej T. Kubanowski - doktorant w Katedrze Teologii Moralnej i Duchowości Wydziału Teologicznego Uniwersytetu Mikołaja Kopernika w Toruniu. Do jego zainteresowań badawczych należą: tomizm biblijny, chrystianologia moralna w myśli św. Tomasza z Akwinu, komentarze św. Tomasza z Akwinu do Listów więziennych św. Pawła, antropologiczne podstawy bioetyki.

${ }^{1}$ Zob. S. T. Pinckaers, Życie duchowe chrześcijanina wedtug św. Pawła i św. Tomasza z Akwinu, tłum. A. Fabiś, Poznań 1998, s. 41.

${ }^{2}$ Chodzi tu nie tyle o samą osobę św. Pawła, lecz o całość tradycji epistolarnej Corpus Paulinum, którą Paweł Apostoł reprezentuje. Taka interpretacja zostaje przyjęta dla całości refleksji prowadzonej dalej. Wszelkie kwestie dotyczące autorstwa poszczególnych listów, zjawiska pseudografii, szczegółowego podziału na listy proto- i deutero-Pawłowe stanowią odrębne tematy do opracowania, niepodejmowane w ramach owego artykułu. 
człowieka i jego conditio humana. Podstawę opinii św. Pawła o człowie$\mathrm{ku}$ stanowią treści zaczerpnięte przez niego z antropologii hebrajskiej, których synteza jest prezentowana w figurze Adama. Zazwyczaj jest ona przedstawiana w negatywnym świetle, jako kategoria „dawnego człowieka" żyjącego poza Bogiem w ramach własnej natury skażonej grzechem,

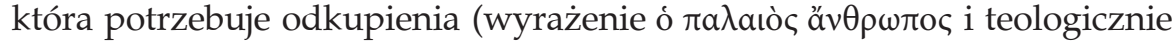
z nim bliskoznaczne sformułowania np. z Rz 5,10; 6,6; 8,5; 8,8; Ef 4,22; 2,12; 4,18; Kol 3,9; 2,20; 1,21 i inne) $)^{3}$. Natomiast główny nurt odpowiedzi Apostoła na antropologiczne pytania świadomie jest przez niego bardziej sprecyzowany i skupiony na chrześcijaninie oraz jego sposobie bycia. Przez to styka się on i łączy z refleksją chrystologiczną. Nie zastępuje jej jednak, ani też nie pomija, lecz korzysta z wypracowanego przez nią teologicznego obrazu Jezusa Chrystusa, w który wpisuje dynamiczną relację ontologiczną chrześcijanina i Boga. Przez ten fakt treści antropologiczne prezentowane przez św. Pawła znajdują się na innym poziomie refleksji teologicznej. Poziom ten wymaga dookreślenia i ponownego zdefiniowania, które będzie właściwsze ze względu na zawartą w nim treść i tematykę. Dlatego właśnie nie należy już mówić wyłącznie o antropologii Pawłowej, lecz również o „chrystianologii” charakteryzującej katechezę Apostoła odnoszącą się do pytań o człowieka4.

We współczesnym dyskursie teologicznym płaszczyzna antropologii teologicznej i „oddolnej” chrystologii często się ze sobą mieszają5 Szczególnie w przypadku rozważań nad nauczaniem św. Pawła nie

${ }^{3}$ Por. J. Gnilka, Pawet z Tarsu. Apostot $i$ świadek, tłum. W. Szymona, Kraków 2001, s. 279-284; R. S. Zdziarstek, Chrystianologia Świętego Pawta, t. 1: Aspekt ontyczny, Kraków 1989, s. 64-82.

${ }^{4}$ Por. E. L. Rehfeld, Relationale Ontologie bei Paulus: die ontische Wirksamkeit der Christusbezogenheit im Denken des Heidenapostels, Tübingen 2012, s. 119-125. Autor dokonuje szczegółowego rozróżnienia myśli antropologicznej św. Pawła. Jeden jej nurt nazywa „chrystianologią", gdyż dotyczy ona wyłącznie refleksji i orędzia „o chrześcijaninie" i „dla chrześcijanina”. Drugi natomiast "hamartologią", ponieważ traktuje on o grzeszniku i jego sytuacji jako "człowieka żyjącego poza Bogiem” lub „człowieka żyjącego według ciała” - „dawnego człowieka”. Co interesujące, E. Rehfeld w nauce Apostoła Narodów przyjmuje pojęciowe rozróżnienie między „hamartologią” a „hamartiologią" - nauką o grzechu, jednakowoż wskazując na ścisłą relację pomiędzy nimi.

${ }^{5}$ Przykładowe publikacje podejmujące to zagadnienie: G. Strzelczyk, Niebezpieczne związki? O wspótzależności chrystologii i antropologii, w: Antropologia miejscem spotkania i dialogu międzyreligijnego, red. G. Kucza, G. Wita, Kraków 2008, s. 117-127; Z. J. Zdybicka, Rola wizji Boga w ksztattowaniu wizji człowieka, w: Wspótczesny fenomen osoby, red. G. Barth, K. Guzowski, Lublin 2011, s. 205-212. 
zawsze dochodzi do pojęciowego sprecyzowania aspektów właściwych antropologii, chrystologii „oddolnej” oraz chrystianologii. Wprowadzenie nowego pojęcia uzupełniłoby dotychczasową refleksję i powstrzymało, nie zawsze uzasadnią, „uniwersalizację” apostolskiego orędzia ${ }^{6}$.

Nazwę „chrystianologia” zaproponował o. Roman S. Zdziarstek OP w swojej pracy doktorskiej pt. "Chrystianologia Świętego Pawła” (1989 r.), w której dokonał ponownej egzegezy i reinterpretacji fragmentów listów Korpusu Pawłowego, wskazujących na zasadność rozważania ich $\mathrm{w}$ ramach nowej dziedziny teologicznej.

Czym właściwie jest owa „chrystianologia”? Najogólniej rzecz ujmując, jest nauką o chrześcijaninie przedstawionym w ontologicznej relacji do Trynitarnego Boga, która kształtuje go i przez upodabniane się do wzoru - Jezusa Chrystusa, prowadzi ku człowieczeństwu uwielbionemu ${ }^{7}$.Aby jednak lepiej zrozumieć istotę „chrystianologii”, należy przedstawić jej krótką genezę.

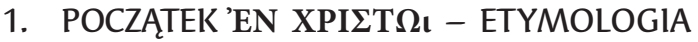

Neologizm „chrystianologia” składa się z dwóch członów. Pierwszy pochodzi od greckiego wyrazu Xpıбтıavó oznaczającego chrześcijani-

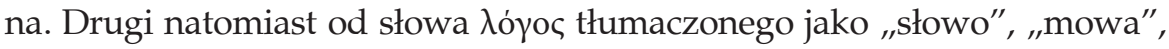
ale także „nauka” lub „wiedza”.

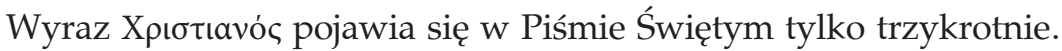

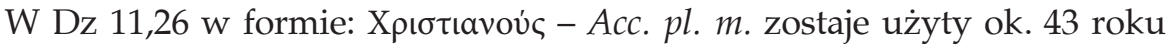
przez mieszkańców Antiochii na określenie uczniów wierzących w Chry-

6 Przesadna „uniwersalizacja” treści pism Pawłowych wynika z niewłaściwego odczytania ich kontekstu i prowadzi do nieodpowiedniego wykorzystywania w procesie ewangelizacji oraz dialogu międzyreligijnego. Należy pamiętać, że listy Corpus Paulinum powstawały we wspólnocie wczesnochrześcijańskiej i były kierowane do jej członków, którzy posiadali już pewne rozeznanie w kwestiach wiary oraz moralności przekazanych przez apostołów.

${ }^{7}$ Por. M. Mróz, Znaczenie obrzędów wyjaśniających chrztu w świetle nauki św. Tomasza z Akwinu o byciu chrześcijaninem, w: Chrzest w życiu i misji Kościoła (V). Liturgia Chrztu Świętego, red. I. Chłopkowska, Warszawa-Siedlce 2010, s. 64; zob. też J. Nagórny, Trynitarny fundament życia moralnego w ujęciu św. Pawła, RTK 29 (1982) 3, s. 53: „Ciekawe, że św. Paweł w odniesieniu do więzi Chrystusa z chrześcijaninem nie mówi wprost o naśladowaniu Chrystusa". Wyraźnie jednak przedstawia życie chrześcijańskie jako „bycie w Chrystusie i z Chrystusem”, przez co bardziej zwraca uwagę na aspekt ontyczny i egzystencjalny owej relacji. 


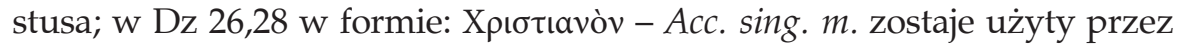
Heroda Agryppę II (w Cezarei Nadmorskiej) i skierowany do Pawła Apostoła w odpowiedzi na jego przemówienie; w 1 P 4,16 w formie:

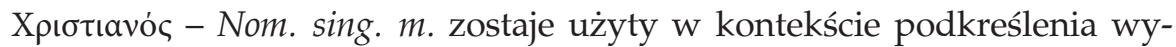

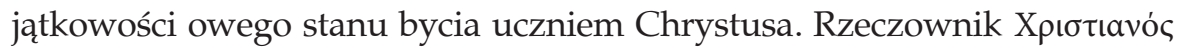
pochodzi od terminu Xpıбтó, który nie jest imieniem własnym Jezusa (chociaż $\mathrm{w}$ pismach nowotestamentalnych nabiera również takiego znaczenia), lecz określa Jego godność i funkcję mesjańską w aspekcie soteriologicznym. Poprzez posiadanie wspólnego tematu wyrazowego

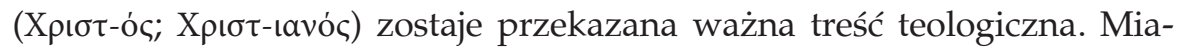
nowicie, chrześcijanin przez wyznawaną wiarę ma udział w mesjańskiej misji Jezusa, zarówno co do zasług, jak i wymagań. Jednak ciężar „bycia Chrystusowym"8 nie spoczywa wyłącznie na osamotnionym człowieku, lecz dzięki ontycznej relacji między wierzącym a Jezusem Chrystusem spada na wyprzedzającą inicjatywę Trójjedynego Boga9

Pomimo że św. Paweł $\mathrm{w}$ swoich listach nie używa nigdzie ter-

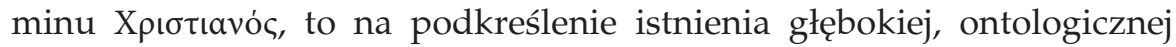
więzi chrześcijanina z Chrystusem stosuje często wyrażenia przyimkowe ukazujące charakter relacyjny, których transparentnym przykładem jest

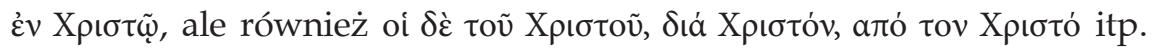

\section{CHRYSTIANOLOGICZNA TERMINOLOGIA}

Opierając się na owym przyimkowym wyrażeniu, Paweł Apostoł zawiera w swoim "chrystianologicznym" nauczaniu sformułowania najczęściej pełniące dwojaką funkcję. Z jednej strony służą określeniu nazwy własnej chrześcijan (np. „żyjący”), z drugiej - przedstawiają ontyczną relację między wierzącym a Chrystusem, a przez Niego również Bogiem Ojcem i Duchem Świętym ${ }^{10}$. Do grupy tych sformułowań należą między innymi:

8 Por. S.Th., II-II, q. 124, a. 5, ad 1: Christianus dicitur qui Christi est.

9 Por. J. Gnilka, Teologia Nowego Testamentu, tłum. W. Szymona, Kraków 2002, s. $428-432$.

${ }^{10}$ Por. R. S. Zdziarstek, "Żyjący-w-Chrystusie” jako jedno z określeń człowieka ochrzczonego w Pawłowej wizji chrześcijanina, w: Agnus et sponsa. Prace ofiarowane o. prof. Augustynowi Jankowskiego OSB, red. T. M. Dą̧ek, T. Jelonek, Kraków 1993, s. 315. 
a) „żyjący w Chrystusie” i paralelne "będący w Chrystusie”, „stworzony w Chrystusie”, „uświęcony w Chrystusie”, „umiłowany przez Jezusa Chrystusa”, "będący w Panu" itp. Pomijając tu szczegółową analizę leksykalno-syntaktyczną kolejnych fragmentów Pisma Świętego, bardzo łatwo dostrzec, że przedstawione formuły pojawiają się wielokrotnie $\mathrm{w}$ pismach Pawłowych. Mają one bardzo wyraźny charakter synonimiczny, który jednoznacznie wskazuje na fakt, że posłużyły one do określenia chrześcijanina. Sposób owego określenia jest bardzo szczególny, gdyż kładzie akcent na ontologiczny aspekt relacji między wiernym a Chrystusem. Człowiek, stając się chrześcijaninem, wchodzi w rzeczywistość „nowego stworzenia”. Egzystencjalna zmiana, jaka się w nim dokonuje, ma charakter realnie ontyczny ${ }^{11}$. Fakt ten domaga się ciągłego urzeczywistniania w aspekcie działaniowym - moralnym. Dlatego właśnie powyższe formuły wskazują na oddziaływanie $\mathrm{w}$ wielu obszarach wspólnie tworzących jedną przestrzeń, w której Jezus Chrystus działa na sposób historyczny (historiozbawczy) oraz mistyczny. Adekwatne wydaje się więc nazwanie owej przestrzeni Mistycznym Ciałem Chrystusa, jednak nie należy jej zamykać wyłącznie w ogólnym pojęciu Kościoła, ale dostrzec też personalny charakter więzi z każdym członkiem. Momentem konstytutywnym dla wejścia w "Chrystusową rzeczywistość" istnienia człowieka jako chrześcijanina jest przyjęcie przez niego sakramentu chrztu. Poprzez swoją symbolikę obrazuje on wydarzenie przejścia ze stanu "dawnego człowieka", żyjącego według „ciała” (paralelnie „świata” - reprezentującego to, co materialne, przemijające), który oznaczał śmierć w znaczeniu eschatologicznym, do stanu "nowego życia w Chrystusie”, mającego charakter nieprzemijający ${ }^{12}$. Nie chodzi tu jednak o odrzucenie ludzkiej fizyczności, lecz bardziej o podkreślenie

${ }^{11}$ Por. A. Gieniusz, Chrzcielne korzenie chrześcijańskiej proegzystencji wedtug Świętego Pawta, w: Agnus et sponsa. Prace ofiarowane o. prof. Augustynowi Jankowskiego OSB, red. T. M. Dąbek, T. Jelonek, Kraków 1993, s. 90.

${ }_{12}$ Zob. J. Gnilka, Pawet z Tarsu, s. 354-360; M. Mróz, Nova vita in Christo. Elementy chrystianologii moralnej św. Tomasza z Akwinu w świetle Wykładu Listu do Kolosan, w: Tomasz z Akwinu, Wyktad Listu do Kolosan. Super Epistolam B. Pauli ad Colossenses lectura, red. i tłum. P. Roszak, Torun 2012, s. 321-323; R. S. Zdziarstek, Chrystianologia, s. $91-138$. 


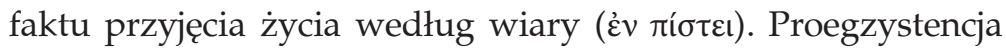
chrześcijańska przebiega właśnie według ram wyznaczonych przez dwa dary pochodzące od Boga: dar życia ludzkiego (fizykalno-psychiczno-duchowego) oraz dar wiary chrystocentrycznie ukierunkowany ku Niemu ${ }^{13}$.

$\mathrm{Z}$ innej perspektywy, w momencie chrztu egzystencja wiernego oraz Chrystusa dynamicznie się ze sobą stykają, przez co natura ludzka zostaje dotknięta łaską uświęcająca, która nie tylko ją odnawia, lecz przemienia $\mathrm{w}$ horyzoncie zbawienia. $\mathrm{W}$ nim dokonuje się swoista inkorporacja w Ciało Chrystusa, w której to dochodzi do zawiązania "organicznej” więzi pomiędzy Chrystusem a wierzącym ${ }^{14}$. Ponieważ w sakramencie chrztu realizuje się całkowita zmiana orientacji ze stanu zakorzenienia w grzechu ku wspólnocie losu wiernego i Pana, ten, który zwraca się ponownie w kierunku rzeczywistości „hamartii”, dopuszcza się znaczącej niekonsekwencji w postępowaniu i lekceważy dzieło samego Boga ${ }^{15}$. Dlatego właśnie osoba ochrzczona, odrzucająca przez postawę i czyny swój status ontyczny, dokonuje analogicznej degeneracji własnej natury jak ta, która miała miejsce w ogrodzie Eden. Ze względu jednak na występowanie niezatartej, ontologicznej relacji między chrześcijaninem a Chrystusem, która konstytuuje się $\mathrm{w}$ chwili chrztu, pierwszy jej podmiot zawsze ma możliwość ponownego zaktualizowania swojego stanu do "teraz bycia w Chrystusie". Stawanie się na wzór Chrystusa jest pewnym procesem, do którego odnoszą się słowa z Kol 3,916. W Pawłowej wizji ów proces polega na nieustannym współumieraniu i współzmartwychwstawaniu,

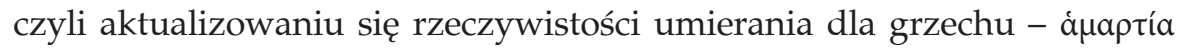
i życia w stanie conformitas Christi dla Boga Ojca - nazwany już wcześniej proegzystencją chrześcijańską ${ }^{17}$. Termin "proegzystencja” wprowadza w tematykę kolejnej grupy sformułowań będących opisem chrześcijanina.

${ }^{13}$ Por. D. Sztuk, "Żyć dla Boga” wedtug Świętego Pawta. Studium egzegetyczno-teologiczne formut dotyczacych proegzystencji chrześcijanina, Warszawa 2006, s. 98-102.

${ }^{14}$ Por. J. Gnilka, Teologia, s. 432-435.

${ }^{15}$ Por. A. Gieniusz, Chrzcielne korzenie, s. 88; R. S. Zdziarstek, Żyjący w Chrystusie, s. 316.

${ }^{16}$ Por. J. Gnilka, Teologia, s. 447-448.

${ }_{17}$ Por. E. J. Jezierska, Bóg Ojciec wobec Syna Pierworodnego i synów przybranych ( $R z$ 4,25 i 2 Kor 4,11), w: Agnus et sponsa. Prace ofiarowane o. prof. Augustynowi Jankowskiego OSB, red. T. M. Dąbek, T. Jelonek, Kraków 1993, s. 152-155. Zdaniem autora umieranie to, oprócz charakteru duchowego, ma również charakter cielesny, który polega na odczuwaniu różnego rodzaju cierpienia fizycznego czy psychicznego, "przeżywaniu” 
b) „wybrany przez Boga”, „powołany”, „umiłowany przez Boga Ojca" itp. w zależności od kontekstu - wyrażenia z użyciem tych formuł służyły do określenia wiernego ochrzczonego, czyli chrześcijanina ${ }^{18}$. To właśnie one pojawiają się w perspektywie odkrycia specyficznych funkcji Boga Ojca w ontycznej „konstrukcji” chrześcijanina. Dwie z nich zostały już wcześniej wspomniane, lecz wymagają pewnego poszerzenia. Chodzi mianowicie o funkcje Boga Ojca ${ }^{19}$ jako Dawcy Życia i Dawcy Wiary (lub też Życia Wiary). Mają one swoje starotestamentalne pochodzenie, z którego korzysta św. Paweł. W pewien sposób obydwie implikują się w obrazie Boga jako Stwórcy, lecz nie wyczerpują całości treści znajdujących się w nim. Samo pojęcie „życia” obejmuje zarówno wymiar przyrodzony - naturalny, który związany jest z fizykalnością, jak również wymiar nadprzyrodzony - duchowy, zawierający aspekt łaski. W tym właśnie aspekcie „życie” oraz „wiara" stykają się ze sobą, tworząc nową rzeczywistość, do której „zapraszany” jest chrześcijanin. Owa rzeczywistość jest przez Apostoła Narodów określania różnymi formułami (najbardziej znamienne są te składające się ze słów „wybranie” oraz jego synonimów, por. Ef 1,4; 2 Tm 1,9; 2 Kor 1,9 i inne), które zawsze odnoszą się do Boga Ojca jako posiadającego całą zbawczą inicjatywę. Motywem Bożego działania jest Jego nieustająca miłość do człowieka, której nie jest $\mathrm{w}$ stanie zmienić sytuacja grzechu ${ }^{20}$. Wejście $\mathrm{w}$ rzeczywistość „Bożego życia” dokonuje się w momencie przyjęcia wiary, która pochodzi nie tylko z rozumowej akceptacji wartości treści

trudności życiowych, prześladowania, odrzucenia, jak również przemijania i starzenia się; por. też Proegzystencja chrześcijańska w ujęciu 2 Kor 5,15, RBL 41 (1988) 1, s. 41 i 43; zob. też M. Mróz, By nie zniweczyć chrystusowego krzyża (1 Kor 1,17). Zrozumienie Misterium Męki i Śmierci Jezusa w świetle niektórych elementów chrystianologii moralnej św. Tomasza z Akwinu, „Teologia i Człowiek” 11 (2008), s. 103.

${ }^{18} \mathrm{~W}$ przeciwieństwie do bpa K. Romaniuka, który na podstawie analizy perykopy Ef 1,3-14, jak również innych fragmentów przedstawia stwierdzenie, iż owe formuły mają charakter powszechny i można odnieść je do każdego człowieka, zob. K. Romaniuk, Zbawcza inicjatywa Boga (wedtug Ef 1,3-14), RBL 18(1965), nr 6, s. 328-346.

${ }^{19}$ Sam motyw Boga jako Ojca w teologii Pawłowej, stanowiący oddzielny temat zainteresowań, jest interesująco podejmowany m.in. w artykule: H. Langkammer, Motyw Boga jako Ojca w teologii św. Pawła, RTK 25 (1979) 1, s. 55-65.

${ }^{20}$ Por. K. Romaniuk, Zbawcza inicjatywa, s. 336-339. 
słowa Bożego zawartego w Objawieniu, lecz przede wszystkim od obdarowującego nią Ojca ${ }^{21}$. Przyjęcie jej przez chrześcijanina domaga się także przyjęcia zobowiązań i powołania, jakie ze sobą niesie. Przede wszystkim jest to nieustanne aktualizowanie chrześcijańskiego życia w wierze, prowadzącego do realizowania woli Boga Ojca względem własnej egzystencji. Dokonuje się to nie tylko na podstawie przykładu życia Jezusa Chrystusa, lecz w ontyczno-moralnej relacji z Nim². Ekspresją owej relacji jest fakt „wydawania” przez Ojca, tak jak Syna Pierworodnego, na śmierć. W przypadku chrześcijanina jest to jednak proces, który ma niszczyć w nim to, co św. Paweł określa mianem „dawnego człowieka”, ,życia według ciała”, "będącego poza Chrystusem” (por. Rz 4,25; 6,6; 2 Kor 4,11; Kol 3,9; Ga 5,19-21) 23. Głównym motywem tegoż „wydawania” jest miłość Boga, która staje się dla chrześcijanina normą jego życia, realizującą się poprzez wypełnianie w zaufaniu Bożej woli ${ }^{24}$. Wypełnianie woli Ojca, według postawy chrystusowej, charakteryzuje się $\mathrm{w}$ chrześcijańskiej praxis: stałą modlitwą, duchem ubóstwa i pokory oraz przede wszystkim miłością Boga i bliźniego posuniętą aż do zaparcia się samego siebie ${ }^{25}$.

Tym, który sprawia, że wierny ochrzczony staje się uczestnikiem „życia wiary", jest Duch Święty działający przez Łaskę ${ }^{26}$.

c) "będący według Ducha”, "będący w Duchu” itp. jako formuły określają chrześcijańską tożsamość, która jest warunkowana poprzez „zamieszkiwanie” Ducha Świętego w chrześcijaninie

${ }^{21}$ Por. P. R. Gryziec, Łaska spotkania chrześcijanina wedtug św. Pawta, RBL 48 (1995) 1, s. 18.

${ }_{22}$ Por. D. Sztuk, Żyć dla Boga, s. 96-97.

${ }^{23}$ Por. E. J. Jezierska, Bóg Ojciec wobec, s. 157; wspomiane już wcześniej podczas opisu formuł chrystycznych.

${ }^{24}$ Por. E. J. Jezierska, Proegzystencja, s. 43; K. H. Schelkle, Teologia Nowego Testamentu, 3. etos, tłum. M. L. Dylewski, Kraków 1984, s. 18-19. Ciekawie tę myśl uzupełnia K. Romaniuk, Zbawcza inicjatywa, s. 345: „Niedostateczne uwzględnienie tego rysu miłości Bożej prowadzi do fałszywego pojęcia odkupienia jako ekspiacji. W rzeczywistości ekspiacja za grzechy nie na tym polega, że Pan Bóg, przebłagany ofiarą złożoną przez Chrystusa, zmienia swe wewnętrzne nastawienie do człowieka [...] Znowu musimy zaznaczyć z całym naciskiem, że zmiana dokonuje się nie w Bogu, jeno przy pomocy Bożej, tylko i wyłącznie w człowieku, a polega na rzeczywistym zniszczeniu grzechu, co czyni człowieka miłym w "oczach» Bożych".

${ }^{25}$ Por. F. Greniuk, Sakramenty źródtem zobowiązań moralnych, RTK 34 (1987) 3, s. 19.

${ }^{26}$ Por. E. J. Jezierska, Bóg Ojciec wobec, s. 157. 
(por. Rz 8,5; Rz 9,9 i inne). W Pawłowej teologii fakt owego „związania” z Duchem objawia się zarówno na płaszczyźnie ontycznej, jak i moralnej. Pomimo że niektórzy autorzy kontestują utożsamianie określania „Duch” z Duchem Świętym i łączą je z "łaską" jako elementem duchowym w człowieku, to jednak w obydwu przypadkach wskazują na stwórczy charakter „Ducha” w chrześcijaninie, który konstytuuje jego status ontyczny i stanowi egzystencjalną podstawę chrześcijańskiego życia. Wierzący, "będący w Duchu”, przez utożsamienie z Duchem Świętym przyjmuje Go jako wewnętrzną normę moralną. Wcześniej wspomniane wypełnianie woli Ojca stanowi realizację owej normy jako postulatu miłości całej Trójcy Świętej, w której chrześcijanin na możliwość partycypować ${ }^{27}$. Formuła „będący w Duchu" jest synonimem formuł z Rz 16,11 czy Rz 8,1, które różnią się tylko ontycznymi punktami odniesienia ${ }^{28}$.

Obecność Ducha Świętego w chrześcijaninie ma u św. Pawła wyraźny charakter chrystocentryczny. Jest ona dynamicznym darem, który rozwija się na trzech, zasadniczych płaszczyznach. Pierwszą z nich jest prowadzenie chrześcijanina ku życiu wiecznemu, któremu cały czas towarzyszy pewne eschatologiczne napięcie pomiędzy „,życiem według ciała” a „życiem według Ducha”. Drugą - przewodnictwo i nieustanny rozwój chrześcijańskiej egzystencji w perspektywie cnót teologalnych oraz darów duchowych. Ostatnią z nich jest płaszczyzna synowskiej relacji między chrześcijaninem a Bogiem, w której najwyraźniej objawia się trynitarny charakter nowego statusu ontycznego, czerpiącego z chrystologicznego sformułowania dotyczącego przybranego synostwa ${ }^{29}$.

\section{3. „PRZYBRANY SYN BOGA" - CHRYSTIANOLOGIA JAKO TEOLOGIA MORALNA}

Powyżej, w ogólnej formie, zostały przedstawione sformułowania wraz z ich teologicznymi znaczeniami, którymi św. Paweł określał wier-

27 Zob. P. R. Gryziec, Łaska spotkania, s. 18: „Człowiek sam z siebie nie może drugiemu udzielać darów nadprzyrodzonych [...]. Jednak jego obecność i kontakt z drugim człowiekiem, staje się okazją działania przezeń Ducha Świętego".

28 Por. R. S. Zdziarstek, Chrystianologia, s. 226-232.

${ }^{29}$ Por. D. Sztuk, Żyć dla Boga, s. 102-105; zob. też K. H. Schelkle, Teologia, s. $34-35$. 
nych chrześcijan. Już na ich podstawie da się zauważyć, że Pawłowa katecheza dotyka kwestii antropologicznych w odniesieniu ich do statusu ontycznego chrześcijanina ( $w$ pewien sposób na zasadzie tezy i antytezy). Inaczej rzecz ujmując, parakleza ${ }^{30}$ apostolska ma wyraźny charakter chrystianologiczny. W szczególny sposób tenże charakter prezentuje się poprzez sformułowanie "przybrany syn Boga”.

Idea przybranego synostwa Bożego, które jest udziałem każdego chrześcijanina, w chrystianologicznej perspektywie jawi się jako podstawa rozważań teologii moralnej ${ }^{31}$. Dlatego właśnie sama chrystianologia może być rozpatrywana również jako nauka o moralności.

Moralność taka nie jest ograniczona do spisu pewnych pouczeń i nakazów. Nie jest również tylko wykładnią Prawa Bożego zawartego w Dekalogu czy Kazaniu na górze. Przede wszystkim skupia się ona na zaprezentowaniu prawdy o ontycznym i moralnym statusie chrześcijanina, ukazanym w perspektywie egzemplaryzmu ontycznego, dla którego miejsce odniesienia stanowi osoba Jezusa Chrystusa, Boga-Człowieka. Jest On wzorem do naśladowania domagającym się dynamicznego „wchodzenia” w Chrystusową rzeczywistość prowadzącą ku Bogu Ojcu, w Duchu Świętym. Poprzez fakt „zaszczepienia” egzystencji chrześcijanina w wymiarze Syna Bożego i nadanie jej statusu przybranego synostwa owa chrystianologiczna moralność jest imitatio Christi, które swoje wypełnienie osiąga w stanie conformitas Christi (o czym szerzej w dalszej części artykułu) ${ }^{32}$.

Tematyka Bożego ojcostwa, a tym samym również Bożego dziecięctwa, ma swoje korzenie w teologii Starego Testamentu, która opierała się na relacji Boga i narodu wybranego. Święty Paweł kontynuuje tę myśl, a jednocześnie urozmaica ją, ukazując w perspektywie daru i zadania całkowicie zależnych od działania Ducha Świętego. Dlatego właśnie podstawowym warunkiem bycia synem Bożym jest życie w Duchu ${ }^{33}$, czyli

${ }^{30}$ Por. J. Gnilka, Pawet, s. 225: „Parakleza, czyli upominanie, obejmuje wiele form ludzkiej, słownej wymiany: od pocieszenia, zachęcenia i przekonywania aż po napominanie".

${ }^{31}$ Nauka moralna widziana w perspektywie synostwa Bożego jest szeroko rozpatrywana w podręczniku do teologii moralnej fundamentalnej: R. Tremblay, S. Zamboni red., Figli nel Figlio. Una teologia morale fundamentale, Bolonia 2008.

32 Por. M. Mróz, Nova vita, s. 323-324.

${ }_{33}$ Ta perspektywa jest interesująco podejmowana przez św. Tomasza z Akwinu w S.Th. I-II, q. 106-108 obejmującej traktat o Prawie Nowym, stojącym u podstaw Tomaszowej koncepcji teologii moralnej. 
wewnętrzna dyspozycja woli chrześcijanina do bycia uległym względem Jego poruszeń. Przez fakt ten owo życie w Duchu ma charakter dynamiczny. Może być doskonalone i rozwijane, jak również osłabiane, aż do całkowitego zaniku. Główną płaszczyzną jego realizacji jest walka pomiędzy duchem a pożądliwościami ciała. Nie wynika z tego, że ciało ludzie jest czymś z natury złym. Staje się ono takie dopiero wtedy, gdy stawiane jest jako główna zasada postępowania, przeciwstawiająca się Bogu. Ciało chrześcijanina powinno służyć mu w realizacji jego powołania do świętości i sprawiedliwości, przezwyciężając złe nawyki, od których on, tak jak każdy człowiek, nie jest jeszcze wolny ${ }^{34}$.

Jednak ta walka między namiętnościami ciała a umysłem nie stanowi o istocie "usynowienia". Znajduje się ona w jego ontycznym charakterze, który góruje nad odniesieniami jurydycznymi czy psychologicznymi ${ }^{35}$. Tenże ontyczny charakter staje się udziałem chrześcijanina w wyniku działania dwóch czynników. Pierwszym z nich jest wiara, której konieczne wyrażenie stanowi chrzest. Drugim, ważniejszym jest sama osoba Jezusa Chrystusa, wraz z Chrystusowym człowieczeństwem, w którym realizuje się Jego zbawcze działanie powodujące zaistnienie statusu synostwa w chrześcijaninie ${ }^{36}$. „Synem Bożym - w pełnym tego słowa znaczeniu - jest tylko Jezus Chrystus [...]", wierni chrześcijanie natomiast są obdarzeni synostwem Bożym w sensie analogicznym, a realizacja ich statusu syna dokonuje się wyłącznie przez Chrystusa (filii in Filio) ${ }^{37}$. Jest On bowiem darem Boga Ojca i jednocześnie Jego Wcielonym obrazem (por. Rz 8,29), będącym żywym drogowskazem dla chrześcijanina ${ }^{38}$.

Pełnia „usynowienia” znajduje się w wymiarze eschatologicznym, który jednak jest już zapoczątkowany w obecnym zjednoczeniu chrześcijanina z Chrystusem, objawiającym się odnowieniem natury ludzkiej i nadaniem jej nowych możliwości. Owocami tego stanu są cnoty (por. Ga 5,22) pomagające w codziennym „odradzaniu” się ku nowemu stworzeniu, którym wierzący staje się na mocy wiary i chrztu ${ }^{39}$.

${ }^{34}$ Por. J. Stępień, Przybrane synostwo Boże w Rz 7-8. Z duchowości św. Pawła, CT 55 (1985) 2, s. 19-20.

35 Por. R. S. Zdziarstek, Chrystianologia, s. 243.

36 Tamże, s. 235-237.

37 Tamże, s. 232-233.

38 Por. E.J. Jezierska, Bóg Ojciec, s. 152-153.

39 Por. J. Stępień, Przybrane synostwo, s. 23-25. 
Stan synostwa jest ściśle związany również z kwestią cierpienia. Aczkolwiek jego sens winien być rozpatrywany w perspektywie nadziei zmartwychwstania. Tak jak Chrystus cierpiał, tak również chrześcijanin, jako syn przybrany, zostaje włączony w ów wymiar paschalny, stanowiący istotę jego imitatio Christi (por. Ga 2,19; Ef 5,1). Jednakże swoje wypełnienie ma w wymiarze rezurekcyjnym, znajdującym się $\mathrm{w}$ stanie pełnego conformitas Christit ${ }^{40}$.

W trochę inny sposób chrystianologię moralną opisuje ks. prof. Mirosław Mróz. Korzystając z pogłębionego studium koncepcji chrześcijańskiej moralności św. Tomasza z Akwinu, ową chrystianologię ukazuje w układzie dwóch egzemplaryzmów. „Chrześcijanin pozostając w ontycznej relacji z Chrystusem (egzemplaryzm ontyczny), kształtuje siebie przez upodobnienie się do «obrazu Chrystusa» (egzemplaryzm moralny) mocą łaski i cnót teologalnych"41. Przez swoją nieskończoną miłość Bóg nie tylko dąży do przywrócenia stanu natury ludzkiej przed grzechem, lecz ukazuje zupełnie nową drogę do siebie, w której priorytetową rolę odgrywa łaska Chrystusowa, a nie samodzielne wysiłki człowieka. To właśnie łaska, udzielana przez Chrystusa całemu Mistycznemu Ciału, umożliwia chrześcijaninowi uczestnictwo w Bożym Życiu i aktualizowanie jego statusu ontycznego, poprzez cnoty teologalne, w urzeczywistniającym się horyzoncie eschatologicznym. Św. Tomasz z Akwinu, który w swojej nauce moralnej opierał się szczególnie na apostolskim nauczaniu św. Pawła, ukazuje perspektywę Boskich cnót wlanych jako podjęcie „kerygmatycznej” formuły z Ga 5,6. „Szczytem orientacji moralnej, według Akwinaty, jest Łaska Ducha Świętego, która przejawia się w wierze działającej przez miłość (S.Th., I-II, q.108, a.1)"42.

Streszczenie całości przeprowadzonego powyżej wywodu może stanowić werset z Flp 1,21. Przy przyjęciu Tomaszowej definicji życia, która łączy je z możliwością poruszania się, tekst ten ukazuje prawdę, że dla moralnego działania chrześcijanina principium stanowi osoba Jezusa Chrystusa. On jest ontologiczną zasadą życia, która sama z siebie aktywizuje oraz stanowi nadrzędny cel chrześcijańskiej egzystencji ${ }^{3}$.

${ }^{40}$ Tamże, s. 25-26.

${ }^{41}$ M. Mróz, Nauka św. Tomasza na kanwie adhortacji Evangelii Gaudium, Referat wygłoszony na wykładzie z okazji liturgicznego wspomnienia Świętego Tomasza z Akwinu w Wyższym Seminarium Duchownym w Pelplinie, Pelplin 28.01.2014.

${ }^{42}$ Tamże.

${ }^{43}$ Por. Tomasz z Akwinu, Super Epistolam B. Pauli ad Philippenses lectura, cap. I, 


\section{CHRYSTIANOLOGICZNA DUCHOWOŚĆ PAWłOWA}

To specyficzne podejście Pawła Apostoła do zagadnień antropologicznych, które są u niego ściśle związane ze sprawami dotyczącymi moralności, wynika ze szczególnego rodzaju duchowości. Duchowość tę można również rozpatrywać w perspektywie chrystianologicznej. Aczkolwiek nie chodzi tu o opis duchowości Pawła Apostoła, lecz refleksję w ramach całego bogactwa treści Corpus Paulinum, bez rozróżnienia na tradycję proto- i deutero-Pawłową.

Źródło owej duchowości stanowi wcześniej już wspominane conformitas Christi, czyli upodobnienie do Chrystusa (por. Flp 1,21) ${ }^{44}$.

Daje się ona określić poprzez charakterystyczne aspekty, takie jak chrystocentryzm, eklezjalność, eschatologiczność, cielesność, teleologiczność oraz intelektualność, ale winna być rozpatrywana zawsze w sposób holistyczny, zakładający wzajemne oddziaływanie i przenikanie się tych wymiarów. Szczególnie jednak duchowość nakreślona przez Listy św. Pawła ma charakter relacyjny, skupiony wokół dwóch zasadniczych kierunków. Są nimi zstępująca relacja od Chrystusa do chrześcijanina oraz wstępująca relacja od chrześcijanina do Chrystusa. Wspólnie można określić je pojęciem wzajemność między Chrystusem a chrześcijaninem, która dokonuje się tak na poziomie indywidualnym, jak również wspólnotowym - małżeńskim oraz eklezjalnym. Relacyjny charakter domaga się u swego początku osobowego spotkania. Takowe ma miejsce $\mathrm{w}$ momencie chrztu, w którym przez wiarę powinno dokonać się radykalnego zawierzenia całego życia Bogu w Chrystusie. Spiritus movens oraz czynnikiem dynamizującym owo zawierzenie się Bogu jest miłość Chrystusowa, którą chrześcijanin przyjmuje na siebie i zaczyna kochać

lec. 3, nr 32: Vita enim importat motionem quamdam. Illa enim vivere dicuntur, quae ex se moventur. Et inde est quod illud videtur esse radicaliter vita hominis, quod est principium motus in eo. Hoc autem est illud, cui affectus unitur sicut fini, quia ex hoc movetur ad omnia. Unde aliqui dicunt illud, ex quo moventur ad operandum, vitam suam, ut venatores venationem, et amici amicus. Sic ergo Christus est vita nostra, quoniam totum principium vitae nostrae et operationis est Christus. Et ideo dicit Apostolus mihi enim vivere Christus est, etc., quia solus Christus movebat eum.; zob. też A. Jankowski, Listy więzienne Świętego Pawta, Poznań 1962, s. 96; H. Langkammer, Komentarz teologiczno-pastoralny wszystkich listów św. Pawła Apostoła z okazji roku Świętego Pawła, t. 2: Listy więzienne Świętego Pawła, Legnica 2010, s. 172.

${ }^{44}$ Por. U. Vanni, Duchowości Pawła, w: Historia duchowości. Duchowość Nowego Testamentu, t. 2, red. R. Fabris, tłum. K. Stopa, Karków 2003, s. 163. 
według niej, przekraczając tym samym granice wszelkiej egoistycznej miłości (por. 1 Kor 13,7). Co niezwykle istotne, Chrystusowa miłość ma charakterystyczny rys osobowy i dlatego może być utożsamiona z Duchem. To właśnie ten Duch wprowadza chrześcijanina w wymiar relacji synowskiej z Bogiem Ojcem i sprawia, że jest on nosicielem i współuczestnikiem miłości trynitarnej, stającej się przy tym czynną zasadą działania dla ducha ludzkiego (por. Rz 8,9;8,26). W tym względzie Jego funkcja jest podwójna i polega $\mathrm{z}$ jednej strony na rozpoznawaniu tego, co w życiu Boże (por. 1 Tes 5,19-21), z drugiej natomiast - na nadaniu „prawa”. Jednakże, jak już wcześniej zostało wspomniane, prawo Ducha nie jest formą kodeksu postępowania zewnętrznie nałożonego na każdego chrześcijanina, lecz żywym Duchem Świętym (por. 2 Kor 3,17), który swoją mocą prowadzi wiernego ku osiągnięciu pełni duchowego życia, wspomagając go w przeciwstawianiu się złym namiętnościom ciała, czyli zabsolutyzowanemu ,ja”, i sprawiając w nim radość z "duchowego owocowania" (por. Ga 5,12). Główną rolą chrześcijanina jest odpowiedź na otrzymany Boży dar. Polega ona na osobowym otwarciu chrześcijańskiej egzystencji na działanie Ducha wraz z konsekwencjami, jakie temu towarzyszą. Owo otwarcie ma mieć nie tylko charakter czysto duchowy, lecz również somatyczny (por. 1 Kor 6,13; 6,20; 10,31). Cielesność bowiem jest bardzo istotnym środkiem nawiązywania i realizowania relacji $\mathrm{w}$ ramach wspólnoty małżeńskiej, rodzinnej oraz eklezjalnej, których głęboko dotyka również duchowość prezentowana w ramach Corpus Paulinum ${ }^{45}$.

Ten "somatyczny" aspekt duchowości według św. Pawła jest ściśle związany również z tematem cierpienia. Cierpienie chrześcijańskie jest jednak zawsze przeżywane w perspektywie Chrystusowej. Jest ono ofiarowywane Bogu i łączy się w swoisty sposób z męką Jezusa Chrystusa (por. Kol 1,24). Przez fakt ten cierpienie doznawane przez chrześcijanina „sakralizuje” jego życie i paradoksalnie jeszcze bardziej utwierdza go w nadziei osiągnięcia Pełni (por. Rz 12,1-2) ${ }^{46}$.

Pełnia bowiem stanowi nadrzędny cel, którego wypatruje duchowość prezentowana w Listach Pawłowych. Jest ona stanem, w którym „człowiek jest cały w Chrystusie, a Chrystus cały w człowieku” (por. 1 Kor 15,28). W wyniku zmiany statusu ontycznego chrześcijanina już w obecnym stanie jego egzystencji ma on pewien duchowy zadatek i partycypacje w Pełni. Jednak nadal jego życie może być określane sformu-

45 Tamże, s. 163-175.

46 Tamże, s. 177. 
łowaniem „bycia w drodze" podzielonej na kilka etapów. Jednym z nich jest śmierć wywołująca pewne egzystencjalne napięcie, którego Pawłowa duchowość nie próbuje przezwyciężać, lecz ukazać w nowej perspektywie dla życia (por. 2 Kor 5,4-5). Drugim natomiast jest związane ze śmiercią przezwyciężenie zła, które wciąż istnieje $\mathrm{w}$ świecie, ale nie ma już szans na zwycięstwo (por. 1 Kor 15,25-28). Zwycięstwo przynależy bowiem jedynie Bogu, a wszystko inne od rzeczywistość Bożej nosi wyłącznie pozory czasowego tryumfü ${ }^{47}$.

Perspektywa ta jest jeszcze wyraźniej nakreślona w Listach więziennych i pasterskich, które w pewien sposób były odpowiedzią na kryzys duchowości występujący we wczesnych wspólnotach. W ich ramach zostaje chrześcijanom ponownie przekazana prawda o ich nowym statusie ontyczny - nowym stworzeniu, którego jedynym sprawcą jest Jezus Chrystus. To właśnie On stanowi centrum chrześcijańskiego życia, a wszystkie inne siły nie mają znaczenia (por. Kol 1-3) ${ }^{48}$.

Kończąc kwestie dotyczącą duchowości Pawłowej, należy stwierdzić, że jej przesłanie oraz zachęta do wprowadzania w życie mają charakter chrystianologiczny, gdyż opierają się na ontycznej i osobowej relacji zachodzącej pomiędzy chrześcijaninem a Trynitarnym Bogiem, widzianym przez pryzmat Jezusa Chrystusa. Chrześcijanie winni być świadomi swojego szczególnego stanu oraz coraz bardziej odkrywać go w ramach wspomnianych aspektów ${ }^{49}$.

\section{PODSUMOWANIE}

"Chrystianologia" jest pojęciem nowym w nomenklaturze teologicznej i niewystarczająco opracowanym. Sama geneza nazwy wprowadza już pewną treść teologiczną opartą na ontologicznej relacji między chrześcijaninem a Chrystusem, która swój początek bierze w sakramencie chrztu.

47 Tamże, s. 181-183.

${ }^{48}$ Por. E. Peretto, Duchowość w pierwszej tradycji chrześcijańskiej, poddanej kryzysowi, w: Historia duchowości, t. 2: Duchowość Nowego Testamentu, red. R. Fabris, tłum. K. Stopa, Kraków 2003, s. 190.

${ }^{49}$ Duchowość pochodząca z listów Pawłowych nie jest jedynym rodzajem duchowości chrześcijańskiej, jednak stanowi jej esencję i wraz z innymi rodzajami duchowości pochodzącymi z Pisma Świętego tworzy podstawę rozwoju życia duchowego każdego chrześcijanina. Duchowość według konkretnych zgromadzeń zakonnych oraz świętych stanowi pewne rozwinięcie owej podstawy. 
Argumenty przemawiające za wyodrębnieniem chrystianologii z refleksji antropologicznej zawartej w listach Corpus Paulinum opierają się głównie na specyficznych sformułowaniach tam używanych. Szczególnie ważne są te, które ukazują charakter relacyjny istoty bycia chrześcijaninem i określają ją przez wyrażenia synonimiczne (np. „będący w Chrystusie”, „wybrany przez Boga”, "będący w Duchu” i inne paralelne). Zwracają one uwagę również na aspekt chrześcijańskiej proegzystencji, czyli „,̇̇ycia całkowicie dla Boga", opartego na ciągłym upodabnianiu się chrześcijanina do Chrystusa we współumieraniu dla grzechu i współzmartwychwstawaniu dla Ojca. Siłą dynamizującą ów proces „uchrystusowienia” jest Duch Święty, a precyzyjniej - łaska Ducha Świętego. Dokonuje On również w chrześcijaninie zawiązania synowskiej relacji z Bogiem, która to stanowi podstawę rozważań teologii moralnej w perspektywie chrystianologicznej.

Charakterystycznym rysem chrystianologii moralnej jest wewnętrzna dyspozycja chrześcijanina do przyjęcia ojcowskiej miłości Boga Ojca, która w postaci łaski Ducha Świętego odnawia naturę ludzką i wyposaża ją w cnoty teologalne oraz duchowe dary. Dzięki nim wierny stara się naśladować swojego Mistrza, aż do osiągnięcia stanu conformitas Christi.

Ta sama chrystianologiczna perspektywa wyraźnie przebija również w duchowości prezentowanej w Listach Pawłowych. Sam św. Paweł jest jej żywym przykładem. Owa chrystianologiczna duchowość charakteryzuje się przede wszystkim otwarciem chrześcijanina na osobową relacje z Bogiem w wydarzeniu Jezusa Chrystusa, ma aspekty dowartościowujące sferę cielesną i ukierunkowaną na osiągnięcie Pełni.

Wyraziście widać, że rozwijanie chrystianologii jako nauki o chrześcijaninie ma swoje uzasadnienie wynikające z treści Listów św. Pawła. Zadanie to wymaga jednak ciągłego pogłębiania refleksji nad apostolskim przekazem, jak również jego egzegezą przeprowadzoną na nowo, która będzie bardziej od syntaktyczno-leksykalnych niuansów skupiać się wokół odczytania kanonicznego, czerpiącego z bogatej tradycji wielkich pisarzy Kościoła.

Podejście chrystianologiczne pozwoli nie tylko na pełniejsze odczytanie paraklezy św. Pawła, lecz przede wszystkim dostarczy nowego spojrzenia na istotę bycia chrześcijaninem, która bywa czasami zafałszowywana.

Streszczenie. Chrystianologia (subdyscyplina antropologii teologicznej) jest nauką o chrześcijaninie będącym w ontycznej relacji z Trójcą Świętą, która formuje go i przez upodobnienie do wzoru - Jezusa Chrystusa, prowadzi do uwielbionego człowieczeństwa. 
We wstępie autor artykułu wskazuje na zasadność wprowadzenia nowej, chrystianologicznej perspektywy do rozważań dotyczących treści antropologicznych zawartych w pismach Corpus Paulinum. W dalszej części argumentuje ów postulat przywołując specyficzne sformułowania pojawiające się w tekstach listów Pawłowych, które opisują i odnoszą się bezpośrednio do ontycznej relacji chrześcijanina z Osobami Trójcy Świętej. Do sformułowań tych należą m.in. "żyjący w Chrystusie”, „będący w Chrystusie”, „umiłowany przez Ojca”, „powołany przez Boga”, „będący w Duchu Świętym" oraz inne paralelne z nimi. Już podstawowa analiza treści teologicznych znajdujących się w nich pozwala stwierdzić, że katecheza Apostoła Narodów skupia się najbardziej na chrześcijaninie będącym w relacji z Trójjedynym Bogiem. Dlatego też zagadnienia antropologiczne są podejmowane w perspektywie chrystianologicznej, która nie tylko wyjaśnia je, lecz również twórczo uzupełnia. Ten aspekt jest szczególnie dostrzegalny w ramach ujmowania chrystianologii jako teologii moralnej. W tak pojmowanej refleksji teologicznomoralnej cel chrześcijańskiej egzystencji jawi się jako osiągniecie stanu pełnego conformitas Christi, do którego prowadzić ma nieustannie działająca Łaska Ducha Świętego. Owo chrystianologiczne podejście $\mathrm{w}$ kwestiach moralnych jest kompatybilne ze szczególnego rodzaju duchowością, która również może być nazwana duchowością chrystianologiczną.

Słowa kluczowe: chrystianologia; relacja ontyczna; Corpus Paulinum; conformitas Christi; antropologia teologiczna.

Abstract: Conformitas Christi - Upon christianology as a study of Christian being. Christianology (subdiscipline of theological anthropology) is a study of Christian being in ontological relationship with the Holy Trinity, which forms him and conforms to the role model - Jesus Christ and also leads him to the adored humanity. In the beginning author suggests that the special formulations used in Corpus Paulinum show relational character of Christian being, e.g. "being in Christ", "chosen by God", "being in Holy Ghost" and parallel. The basic analyze of these theological contents allows to ascertain that St. Paul's paraklesis is focused on Christian being in ontological relationship to Holy Trinity. Hence, most of anthropological questions are brought up in christianological perspective, which completes them. This aspect is noticeable when the christianology is conceptualized as a moral theology. In this moral christianology the purpose of Christian being is to achive a state of conformitas Christi. The Holy Ghost's Grace leads believer to this aim. A christianological persective in moral theology is compatible with particular type of Christian spirituality form Corpus Paulinum. Therefore it can be named christianological spirituality.

Keywords: christianology; ontological relationship; Corpus Paulinum; conformitas Christi; theological anthropology. 
